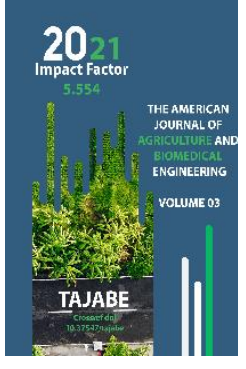

Journal Website: https://theamericanjou rnals.com/index.php/ta jabe

Copyright: Original content from this work may be used under the terms of the creative commons attributes 4.0 licence.

\section{Characteristic Of Adaptive Capacity Of Families Of Thin Fiber Cotton In The Conditions Of Tashkent And Surkhandarya Regions}

\author{
Kamoladdin Khudarganov \\ Doctor Of Agricultural Sciences, Head Of The Laboratory, Research Institute For Quarantine \\ And Plant Protection Agency For Quarantine And Plant Protection Of The Republic Of \\ Uzbekistan
}

\title{
ABSTRACT
}

It was established, that the studied lines and families have a high adaptive ability. Significant differences in most of the studied traits between the lines were not noted, but there was a slight excess in the number of boxes in L-51 and the height of the main stem in line L-52.

At present, the issues of identifying and creating adaptive forms characterized by the stability of the main economically valuable traits have acquired particular importance. One of the important indicators characterizing the resistance of plants to the influence of unfavorable environmental factors is homeostasis, which is a universal property in the system of the relationship between the genotype and the external environment. Homeostasis is nothing more than the ability of the genotype to minimize the effects of exposure to adverse external conditions.

Selection and seed production of agricultural plants are an integral part of adaptive crop production, and they play a leading role in the biologization and greening of intensification processes.

\section{KEYWORDS}

Tashkent, Surkhandarya Regions, Fiber Cotton.

\section{INTRODUCTION}

In general, the direction of the adaptive breeding system has now become a priority all over the world, acting as one of the most important factors in the transition to adaptive crop production. 
According to A.A. Zhuchenko. [1], with the adaptability of agricultural plants, ie. their stability, ability to withstand the action of damaging environmental factors, an increase in their productivity is inextricably linked. Over the past 30 years, the contribution of breeding to increasing the yield of the most important agricultural crops is estimated at $40-80 \%$. In the future, the role of the biological component, and first of all, of the breeding improvement of varieties and hybrids in increasing the size and quality of the crop, will continuously increase.

Breeding for resistance to unfavorable environmental factors presupposes the availability of an appropriate source material, the use of various artificially created backgrounds for the study of the source and breeding material, its wide environmental testing and a comprehensive assessment of breeding material, starting from the early stages of breeding. The growth of the size and quality of the crop in unfavorable, and, even more so, in extreme conditions, primarily depends on the success in increasing the resistance of varieties to unfavorable environmental factors.

It is generally accepted that $25 \%$ of the yield is determined by the genetic characteristics of the cultivated varieties. The role of the genotype in increasing and stabilizing yields is constantly increasing, and the contribution of the variety to zoning, according to T.V. Borisovtsa. [2] is estimated at 30 ... 50\%. A variety as a means of agricultural production is one of the most important elements ensuring the receipt of the required amount of highquality products.
The current crop breeding strategy is aimed at increasing yields and adaptability to spring frosts, droughts, dust storms, a complex of diseases, pests and other environmental stressors. In this regard, the identification of the type of inheritance of selectively valuable traits in hybrid combinations created on the basis of new donors and genetic sources, the purposeful use of transgressive variability remain important problems of breeding. The breeding potential of hybrid populations of soft winter wheat is determined by the study of the inheritance of the most important economically valuable traits in hybrids in F1 with the appearance of heterosis and positive dominance. Genotypes isolated in subsequent generations from such populations are characterized by an increase in the severity of individual traits, sometimes in the development of a complex of traits, which enhances their plasticity and adaptability under limited environmental conditions [3].

Since it is genetic recombinations, and not mutations, that serve as the main source of adaptive genotypic variability in plants, and the methods of introgressive and transgressive plant breeding are based only on their use, special attention should be paid to increasing the potential productivity of those plant species that already possess evolutionarily determined resistance to unregulated environmental factors and the creation of a selection-geographical and variety-testing network, typing the soil and climatic features of different regions [4].

\section{MATERIAL AND RESEARCH METHODS}

In the Tashkent and Surkhandarya regions, a comparative study of the adaptive potential of 
The American Journal of Agriculture and Boimedical Engineering (ISSN - 2689-1018)

the breeding lines L-51 (F1B1 [F1 T-817 x 010972) x T-817] x Surkhan-9) x T-741 was carried out; L52 (F1B1 [F1 T-817 x 010972) x T-817] x (F1 Surkhan-16 $\times$ Surkhan-18) and families of the SP-7701 variety of fine-fiber cotton. In the Tashkent region, sowing was carried out according to the 60x30-1 scheme, in the Syrdarya region, according to the $90 \times 30 \times 1$ scheme. The experiment was carried out in triplicate with 20 well plots. Statistical processing of the obtained digital material was carried out according to Dospekhov, [5].

\section{RESEARCH RESULTS}

In the conditions of Surkhandarya region, we studied promising lines and families of finefiber cotton. In the conditions of Surkhandarya region, lines L-51 and families of the SP-7701 variety were studied. For the L-51 line, the weight of raw cotton per box was $3.8 \mathrm{~g}$, for the SP-7701 variety the indicators were slightly lower and amounted to $3.1 \mathrm{~g}$. In the L-51 line, the seeds have gray pubescence, and in the SP7701 variety, there is slight pubescence on the seed chalase.

Table 1 shows the characteristics of economically valuable traits in the line and variety of fine-fiber cotton in the conditions of the Surkhandarya region.

Table 1

Characteristics of economically valuable traits in the line and variety of fine-fiber cotton in the conditions of the Surkhandarya region.

\begin{tabular}{|c|c|c|}
\hline Economically valuable signs & Л-51 & CП-7701 \\
\hline Fiber output,\% & $38,4 \pm 0,14$ & $39,4 \pm 0,21$ \\
\hline Limit of variability & $37,1-40,8$ & $37,4-43,2$ \\
\hline Homeostatic index & 1428 & 1041 \\
\hline Weight of 1000 seeds, $g$ & $130,1 \pm 1,14$ & $104,9 \pm 0,47$ \\
\hline Limit of variability & $111,2-143,5$ & $100,0-114,0$ \\
\hline Homeostatic index & 2078 & 3285 \\
\hline Fiber length, mm & $40,8 \pm 0,16$ & $40,1 \pm 0,11$ \\
\hline Limit of variability & $38,6-43,8$ & $39,0-42,4$ \\
\hline Homeostatic index & 1404 & 1986 \\
\hline
\end{tabular}

From the presented data, it can be seen that the SP-7701 variety has a higher average fiber yield of $39.4 \%$ with the variability limit of this trait of 37.4-43.2\% and the homeostatic index of 1041. The average indicators of this trait in line L-51 were $38,4 \%$ with a limit of variability of
$37.1-40.8 \%$ and a homeostatic index of 1428 higher than that of the SP-7701 variety. By the weight of 1000 seeds, in addition to the homeostaticity index, an excess was noted compared to SP-7701. So the average indicator of the mass of 1000 seeds was $131.1 \mathrm{~g}$ with the 
The American Journal of Agriculture and Boimedical Engineering (ISSN - 2689-1018)

variability limit of $111.2-143.5 \mathrm{~g}$ and the homeostatic indicator of 2078. In the SP-7701, the average indicator of this trait was $104.9 \mathrm{~g}$ with the variability limit of 100.0-114.0 g and the indicator homeostaticity 3285. Similar indicators were obtained for the attribute of fiber length. Thus, the average fiber length in L51 was $40.8 \mathrm{~mm}$ with a limit of variability of 38.6-43.8 $\mathrm{mm}$ and a homeostatic index of 1404 . For SP-7701, the average indicator of this trait was $40.1 \mathrm{~mm}$ with a limit of variability of 39.0$42.4 \mathrm{~mm}$ and the index of homeostaticity 1986.
From the given data it is clear that the highest indicators of homeostaticity, in addition to the sign of fiber yield, were noted in SP-7701. This shows that the characteristics of the mass of 1000 seeds and the length of the fiber are the most stable in SP-7701. The material is more aligned with the fiber output at the L-51 line. The research results showed that the studied materials have a high adaptive ability and in the conditions of the Surkhandarya region retained their indicators.

table 2

\section{Characterization of morphological characters in lines of fine-fiber cotton on a wilt background} (Tashkent region).

\begin{tabular}{|c|c|c|}
\hline Morphological signs & \multicolumn{1}{|c|}{-51} & Л-52 \\
\hline Bookmark height of the first sympodial branch, nodes & $3,8 \pm 0,07$ & $3,8 \pm 0,07$ \\
\hline Limit of variability & $3-6$ & $3-6$ \\
\hline Homeostatic index & 21 & 21 \\
\hline Number of monopodial branches, pieces & 0,9 & 0,2 \\
\hline Number of sympodial branches, pieces & $30,1 \pm 0,38$ & $33,1 \pm 0,48$ \\
\hline Limit of variability & $22-48$ & $23-47$ \\
\hline Homeostatic index & 217 & 210 \\
\hline Number of boxes, pieces & $35,7 \pm 0,51$ & $33,1 \pm 0,59$ \\
\hline Limit of variability & $23-49$ & $22-49$ \\
\hline Homeostatic index & 230 & 172 \\
\hline Main stem height, cm & $85 \pm 0,97$ & $103 \pm 1,37$ \\
\hline Limit of variability & $70-120$ & $70-145$ \\
\hline Homeostatic index & 682 & 712 \\
\hline
\end{tabular}

We studied lines of fine-stapled cotton L-51 and L-52 against a wilt background in the Tashkent region. Table 2 shows the characteristics of morphological characters in lines of fine-fiber cotton on a wilt background in the Tashkent region.

From the data presented, it can be seen that the average values of the height of the initiation of the first sympodial branch did not differ between the lines and amounted to 3.8 nodes with the limit of variability of 3-6 nodes and homeostaticity of 21 . Line L-51 had more monopodial branches. The average valuesof the number of sympodial branches were 30.133.1 pieces, with more of them formed in the L52 line. The limit of variability of this trait was 
The American Journal of Agriculture and Boimedical Engineering

(ISSN - 2689-1018)

IMPACT FACTOR

Published: December 30, 2021| Pages: 9-14

Doi: https://doi.org/10.37547/tajabe/Volume03Issue12-03

2021: $5 \cdot 554$

OCLC - 1121105746

22-48 pieces and with a homeostatic index of 210-217. The average values of the number of formed bolls were 33.1-35.7 pieces with the limit of variability of 22-49 pieces and with a homeostatic index of 172-230. The highest homeostaticity values were obtained for the L51 line. The height of the main stem was 85-103 $\mathrm{cm}$ with the limit of variability $70-145 \mathrm{~cm}$ and homeostaticity 682-712. Higher values of the height of the main stem were observed in plants of line L-52.

\section{CONCLUSION}

Based on the research conducted, conclusions can be drawn:

1. The studied lines $L-51$ and $L-52$ have a high adaptive ability and in the conditions of the Surkhandarya region retained their performance.

2. Analysis of morphological characters in lines L-51 and L-52 under the conditions of the Tashkent region showed that there were no significant differences in most of the studied characters between the lines, but there was some excess in the number of bolls in L-51 and the height of the main stem in line L- 52.

3. In the conditions of the Tashkent region, in complex hybrids of fine-staple cotton, in comparison with a simple hybrid combination, an excess of the weight of raw cotton of one box, the weight of 1000 seeds was observed.

For practical breeding, it is recommended to use lines of fine-fiber cotton L-51 and L-52.

\section{REFERENCES}

1. Жученко А.А. Стратегия адаптивной интенсификации сельского хозяйства (концепция) / А.А. Жученко.-Пущино: ОтА. НТИ Пущ. науч. Центра РАН, 1994.-148 с.

2. Борисовец Т. Экономическое содержание и факторы интенсификации зернового производства /Т. Борисовец // Агроэкономика.-2000.-№3.-С.30-32.

3. Мельникова О. В., Грабовец А.И., Фоменко М.А. Наследование хозяйственно ценных признаков гибридами мягкой озимой пшеницы в степной зоне ростовской области. Известия государственного аграрного университета ном.4 (60), 2016 с.17

4. Кильчевский А.В. Экологическая селекция растений / А.В. Кильчевский, Л.В. Хотылёва. - Минск : Тэхналогія, 1997. - 372 с.

5. Доспехов Б.А. Методика полевого опыта. - Колос, 1979. - 416 С.

6. Муродов Б.Э., Сулаймонов О.А., Яхёев Ж.Н. Калифорнийская щитовка на яблоне // Образование и наука в России и за зарубежом. - 2018. - № 12 (47). - C. 118-122.

7. Murodov B.E., Ortikov U.D., Yakhyoyev J.N. Bioecology of california shield (Quadraspidiotus perniciosus Comst) in Uzbekistan / Proceedings of International Multidisciplinary Scientific Conference on Innovative Technology. Organized by Novateur Publications, India. May 25th, - 2020. P. 104-107. 
The American Journal of Agriculture and Boimedical Engineering

IMPACT FACTOR (ISSN - 2689-1018)

Published: December 30, 2021| Pages: 9-14

Doi: https://doi.org/10.37547/tajabe/Volume03Issue12-03

OCLC - 1121105746

8. Муродов Б.Э., Ортиков У.Д., Яхёев

Ж.Н. Биоэкология и развития

калифорнийской щитовки

(Quadraspidiotus perniciosus Comst.)

в Узбекистане // Евразийский Союз

Ученых (ЕСУ). - 2020. - 5 (74). - С. 39-

40.

9. Машарипов У.А. Городской усач (Aeolesthes sarta Solsky) - вредитель лесных насаждений // Актуальные проблемы современной науки. 2020. 1 (110). - C. 108-110. 